African Journal of Biotechnology Vol. 11(8), pp. 1855-1861, 26 january, 2012

Available online at http://www.academicjournals.org/AJB

DOI: $10.5897 / A J B 11.2454$

ISSN 1684-5315 @ 2012 Academic Journals

Full Length Research Paper

\title{
Association analysis of PRKAG3 gene variants with carcass and meat quality traits in beef cattle
}

\author{
Wu-Feng $\mathrm{Li}^{1,2}$, Jun-Ya $\mathrm{Li}^{2}$, Xue Gao ${ }^{2}$, Shang-Zhong $\mathrm{Xu}^{2}$ and Wen-Bin Yue ${ }^{1 *}$ \\ ${ }^{1}$ College of Animal Science and Technology, Shanxi Agricultural University, Taigu, China. \\ ${ }^{2}$ Institute of Animal Science, Chinese Academy of Agricultural Sciences, Beijing, China.
}

Accepted 4 November, 2011

\begin{abstract}
The bovine PRKAG3 gene encodes a muscle-specific isoform of the regulatory gamma-subunit of adenosine monophosphate activated protein kinase (AMPK), which plays a key role in regulating energy homeostasis in eukaryotes. It is well known that mutations in the PRKAG3 gene affect high glycogen content in the porcine skeletal muscle and, consequently, meat quality. Therefore, this gene has been proposed as a positional and functional candidate gene for a quantitative trait locus (QTL) with an effect on meat quality traits. In this study, we detected four single nucleotide polymorphisms (SNPs) at the PRKAG3 gene (DQ082736) in 267 beef cattle. The SNP marker association analysis indicated that the SNP markers T2885C was significantly associated with tenderness trait. Animals with the TT genotype had lower Warner-Bratzler shear force (WBS) than those with the other genotypes. Results of this study suggest that the PRKAG3-gene-specific SNP may be a useful marker for meat quality traits in future marker-assisted selection programmes in beef cattle.
\end{abstract}

Key words: Association analysis, beef cattle, single nucleotide polymorphism (SNP) polymorphism, PRKAG3 gene.

\section{INTRODUCTION}

In cattle, tenderness is the primary quality attribute for consumer acceptance of meat, followed by juiciness and flavor. Extensive efforts are being made to control and improve these qualities but are still impaired by the fact that these characters are subjected to many genetic and environmental factors and the elucidation of the mechanisms involved requires extensive studies (Roux et al., 2006).

The adenosine monophosphate (AMP)-activated protein kinase (AMPK) has been pointed out as one of the main actors in the regulation of intracellular energy metabolism (Carling, 2004). AMPK is activated by phosphorylation of the a-subunit at threonine 172. The phosphorylation is catalysed by an upstream kinase, the AMP-activated protein kinase kinase (AMPKK), which in

\footnotetext{
*Corresponding author. E-mail: simmenta@vip.sina.com, wb_yue@126.com.
}

turn is directly activated by AMP (Hawley et al., 1996) or by the binding of AMP to AMPK and AMPKK (Hardie et al., 1998). AMPK is activated by the catabolic pathway responsible for the switch to aerobic metabolism, which is necessary to sustain exercise for a long period. Once AMPK is activated, it stimulates both an increase in fatty acid oxidation and an increase in glucose uptake to meet the energy demands of the working muscle (Winder, 2001).

Numerous mechanisms of AMPK action on lipid and carbohydrate metabolism have been proposed (Ferre et al., 2003; Hardie et al., 2003). AMPK is a heterotrimeric enzyme complex comprising a catalytic a subunit and regulatory $\beta$ and $y$ subunits. Seven different isoforms ( $\alpha 1$, $\alpha 2, \beta 1, \beta 2, \gamma 1, \gamma 2$ and $\gamma 3$ ), each encoded by a different gene, have been characterized so far and all the combinations (12 in total) are possible. The different combinations depend on the tissue type and they have different levels of activity.

The y3-peptide, encoded by the PRKAG3 gene, is one 
Table 1. Number of records, means and standard deviations for traits analyzed in this study $(\mathrm{N}=267)$.

\begin{tabular}{lcc}
\hline Trait & Mean & SD \\
\hline Live weight $(\mathrm{kg})$ & 548.15 & 64.05 \\
Carcass weight $(\mathrm{kg})$ & 301.13 & 39.50 \\
Dressing percentage (\%) & 55.00 & 0.03 \\
Backfat thickness $(\mathrm{cm})$ & 1.03 & 0.45 \\
Loin muscle area $\left(\mathrm{cm}^{2}\right)$ & 68.81 & 12.82 \\
Meat color (1-6) & 4.45 & 0.74 \\
Fat color (1-7) & 1.32 & 0.41 \\
Marbling score (1-5) & 2.14 & 1.00 \\
Tenderness (kg) & 3.95 & 1.40 \\
\hline
\end{tabular}

of the three $y$-isoforms for the $\mathrm{y}$-regulatory subunit of AMPK and shows muscle specific expression (Stapleton et al., 1996; Thornton et al., 1998; Kemp et al., 1999; Cheung et al., 2000). Previous work has indicated that the PRKAG3 gene affects the glycogen content in muscle and hence, meat quality traits in pigs, including ultimate $\mathrm{pH}$, meat color, water-holding capacity, drip loss, tenderness and cooking loss (Milan et al., 2000; Ciobanu et al., 2001).

Knowledge of muscle biochemical characteristics related to meat quality in cattle is still limited. However, it is now well established that there is an important variability in muscle biology which is directly associated with downstream parameters like postmortem meat maturation, drip loss, cooking loss, tenderness, juiciness and taste. This is because of the large effect of AMPK $\mathrm{Y} 3$ subunit mutations on muscle glycogen content and $\mathrm{pH}$ observed in pig and the close association between glycogen metabolism, $\mathrm{pH}$, and meat quality in cattle (Immonen et al., 2000).

The objectives of this study were to detect polymorphisms in the PRKAG3 gene, and to analyze associations between these polymorphisms and carcass and meat traits in several cattle breeds. The results of this study could add new evidence that PRKAG3 is an important candidate gene to be used for selection of meat traits in the beef cattle industry.

\section{MATERIALS AND METHODS}

\section{Animals, carcass and meat quality data}

A total of 267 animals, including Simmental $(N=107)$, Angus $(N=$ $44)$, Hereford $(N=30)$, Charolais $(N=28)$, Limousin $(N=19)$, Luxi $(N=20)$ and Jinnan $(N=19)$, were randomly selected from commercial populations and used in the association analysis. The animals (405 $\pm 50.5 \mathrm{~kg} ; 30 \pm 2$ months of age at slaughter) were reared in the provinces of Inner Mongolia and Hebei. Carcass and meat quality traits were measured according to the criterion $\mathrm{GB} / \mathrm{T}$ 17238-1998 Cutting Standard of Fresh and Chilled Beef in China (China Standard Publishing House). Nine traits were measured or calculated (Table 1): live weight (LW), carcass weight (CW), dressing percentage (DP), backfat thickness (BF), marbling score (MS) loin muscle area (LMA), meat color (MC), fat color (FC) and tenderness (TD). BF and LMA were measured between the 12 and 13th rib. MC, FC and MS for quality grade were evaluated on a cross section of the loin muscle between the 12 and 13th rib, which are scored on a scale of 1 to 7,1 to 7 and 1 to 5 , respectively. TD was also measured on a cross section of the loin muscle between the 12 and 13th rib, the measurement type is called measurement of Warner-Bratzler shear force (WBS), which was recorded in kg. All experimental procedures were performed according to authorization granted by the Chinese Ministry of Agriculture.

\section{Polymerase chain reaction (PCR) amplification and sequencing}

DNA samples were extracted from blood samples according to

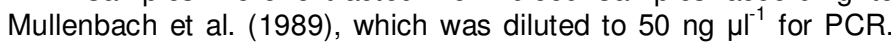
According to the bovine PRKAG3 gene sequence cloned in the 8048 bp DNA sequence (published data: DQ082736), four pairs of primers were designed to amplify four fragments (checked by DNA sequencing) within it (Table 2). PCR amplifications were performed in a $30 \mu \mathrm{l}$ volume containing $50 \mathrm{ng}$ of DNA template, $10 \mathrm{pM}$ each primer, $0.20 \mathrm{mM} \mathrm{dNTP}, 2.5 \mathrm{mM} \mathrm{MgCl}$, and $0.5 \mathrm{U}$ of DNA Taq polymerase (TaKaRa, Dalian, China). The PCR protocol was $94^{\circ} \mathrm{C}$ for $5 \mathrm{~min}$, followed by 35 cycles of $94^{\circ} \mathrm{C}$ for $30 \mathrm{~s}$, annealing for $30 \mathrm{~s}$ and $72{ }^{\circ} \mathrm{C}$ for 30 to $60 \mathrm{~s}$, and a final extension at $72^{\circ} \mathrm{C}$ for $10 \mathrm{~min}$. The products were purified by using a Wizard Prep PCR purification kit (Shanghai Bioasia Biotechnology, P. R. China) and sequenced (Beijing Aolaibo Biotechnology, P. R. China; Applied Biosystems 3730xI DNA sequencer, Foster city, CA, USA).

\section{Polymorphism discovery and PCR-restriction fragment length polymorphism (RFLP) analysis}

Four polymorphisms were identified by sequencing (Figure 1) and confirmed by PCR-RFLP using Bfm I (primer sets 1), Bcn I (primer sets 2), Rsa I (primer sets 3 ) and Tai I (primer sets 4) restriction enzymes (New England BioLabs, Beverley, MA, USA). A1428G site has three genotypes, which are GG (221bp), AG (221/119/102bp) and AA (119/102bp); T2643C site has three genotypes, which are TT (230/96bp), TC (230/187/96/43bp) and CC (187/96/43 bp); T2885C site has three genotypes, which are TT (203 bp), TC (203/104/99 bp) and CC (104/99 bp); G3869C site has three genotypes, which are CC (669/174bp), GC (669/559/174/70bp) and 
Table 2. Primer sequences used for amplification and polymorphism in the bovine PRKAG3 gene.

\begin{tabular}{clcccc}
\hline $\begin{array}{c}\text { Fragment }^{\text {a }} \\
\text { (primer sets) }\end{array}$ & Sequence (5'-3') & $\begin{array}{c}\text { PCR product } \\
\text { size(bp) }\end{array}$ & $\begin{array}{c}\text { Genomic } \\
\text { position }\end{array}$ & $\begin{array}{c}\text { SNP } \\
\text { location }\end{array}$ & $\begin{array}{c}\text { Nucleotide } \\
\text { polymorphism }\end{array}$ \\
\hline P1 & $\begin{array}{l}\text { F: CTCTCGCCTCCTTCCTCTTT } \\
\text { R: TCCAAAGGTCTTTTCCTCCA }\end{array}$ & 221 & Intron2 & 1428 & A/G \\
P2 & $\begin{array}{l}\text { F: CAAGCTGGTCATCTTCGACA } \\
\text { R: AAATGCTCCCAGTCATCCTG }\end{array}$ & 326 & Intron4 & 2643 & T/C \\
P3 & $\begin{array}{l}\text { F: CAGGATGACTGGGAGCATTT } \\
\text { R: CCATACGTGCTGGTTGTAGC }\end{array}$ & 203 & Intron4 & 2885 & T/C \\
P4 & F: GGTAAACCCCACTCCTCTCTCT & 843 & Exon7 & 3869 & G/C \\
\hline
\end{tabular}

${ }^{\mathrm{a}}$ The position of fragments are shown in Figure 1.

GG (599/174/70 bp) (Figure 2).

\section{Statistical analysis}

The associations between SNP marker genotypes of the PRKAG3 gene and carcass and meat quality traits were analyzed by the least-squares method as applied in the GLM procedure of SAS (SAS Institute Inc., Cary, NC, USA) according to the following linear model:

$Y_{i j k l}=\mu+B F_{i}+$ Month $_{j}+G_{k}+e_{i j k l}$

Where, $Y_{i j k l}=$ observed value; $\mu=$ overall mean for each trait; $B F_{i}=$ fixed effect of $i^{\text {th }}$ breed and farm; Month $h_{j}=$ fixed effect of $j^{\text {th }}$ month of slaughtering; $G_{k}=$ fixed effect of $k^{\text {th }}$ single SNP marker genotype; $e_{i j k l}=$ random error.

\section{RESULTS AND DISCUSSION}

We amplified and sequenced four fragments at the PRKAG3 gene (GenBank accession number DQ082736) in 267 animals. The comparisons among these sequences revealed four mutations: A1428G, T2643C, T2885C and G3869C (Figure 1). Sequence analysis showed that these alleles were caused by $A$ to $G, T$ to $C$, $T$ to $C$ and $G$ to $C$ mutations at positions $1428,2643,2885$ and 3869, respectively. The allele and genotype frequencies of the four SNPs are shown in Table 3.

The genotypes of 267 individuals were tested for correlation with phenotypic data for nine traits. The gene-specific SNP marker correlation analysis indicated that the SNP marker T2885C was significantly correlated with tenderness trait $(P<0.05)$. Animals with the TT genotype had lower tenderness WBS value than those with TC and CC genotypes $(P<0.05)$ (Table 4). No significant correlations were observed between any of the marker genotypes at T2885C and other traits. The other SNPs showed no significant association with traits examined in this study.
Rothschild et al. (2005) gained the US Patent for they found PRKAG3 alleles and use the same as genetic markers for reproductive and meat quality traits in pigs. Roux et al. (2006) reported the bovine PRKAG3 gene and a polymorphism analysis in three cattle breed; 32 SNPs were identified among which 13 are in the coding region, one is in the 3' UTR and 18 are in the introns; five of them change an amino acid in the PRKAG3 protein sequence; allelic frequencies were determined in the three breeds considered, and mutant alleles affecting the coding sequence were found at a very low frequency. Similarly, $\mathrm{Yu}$ et al. (2005) also reported that the genomic structure and sequence of the bovine PRKAG3 were analyzed from a Korean cattle BAC clone; the bovine PRKAG3 gene comprises 13 exons and spans approximately $6.8 \mathrm{~kb}$ on BTA2; from 5' and 3'-rapid amplification of CDNA ends experiments, the full-length cDNA of bovine PRKAG3 had been identified, encoding a deduced protein of 465 amino acids; seven single nucleotide polymorphisms were detected in four Bos taurus cattle breeds; the bovine PRKAG3 gene described in that study might be involved in muscle-related genetic diseases or meat quality traits in cattle.

However, in the study of these two groups, they did not measure any associated traits, and also did not test association analysis.

Therefore, in our study, by measuring carcass and meat quality traits and association analysis of gene-specific SNP markers in 267 animals, we found a significant correlation between the T2885C SNP in the PRKAG3 gene and tenderness trait. Since the power of detection of associations for such a relatively small sample size as ours is low, we cannot exclude the possible association with other traits considered.

\section{Conclusions}

Our results provide evidence that the PRKAG3 gene has 

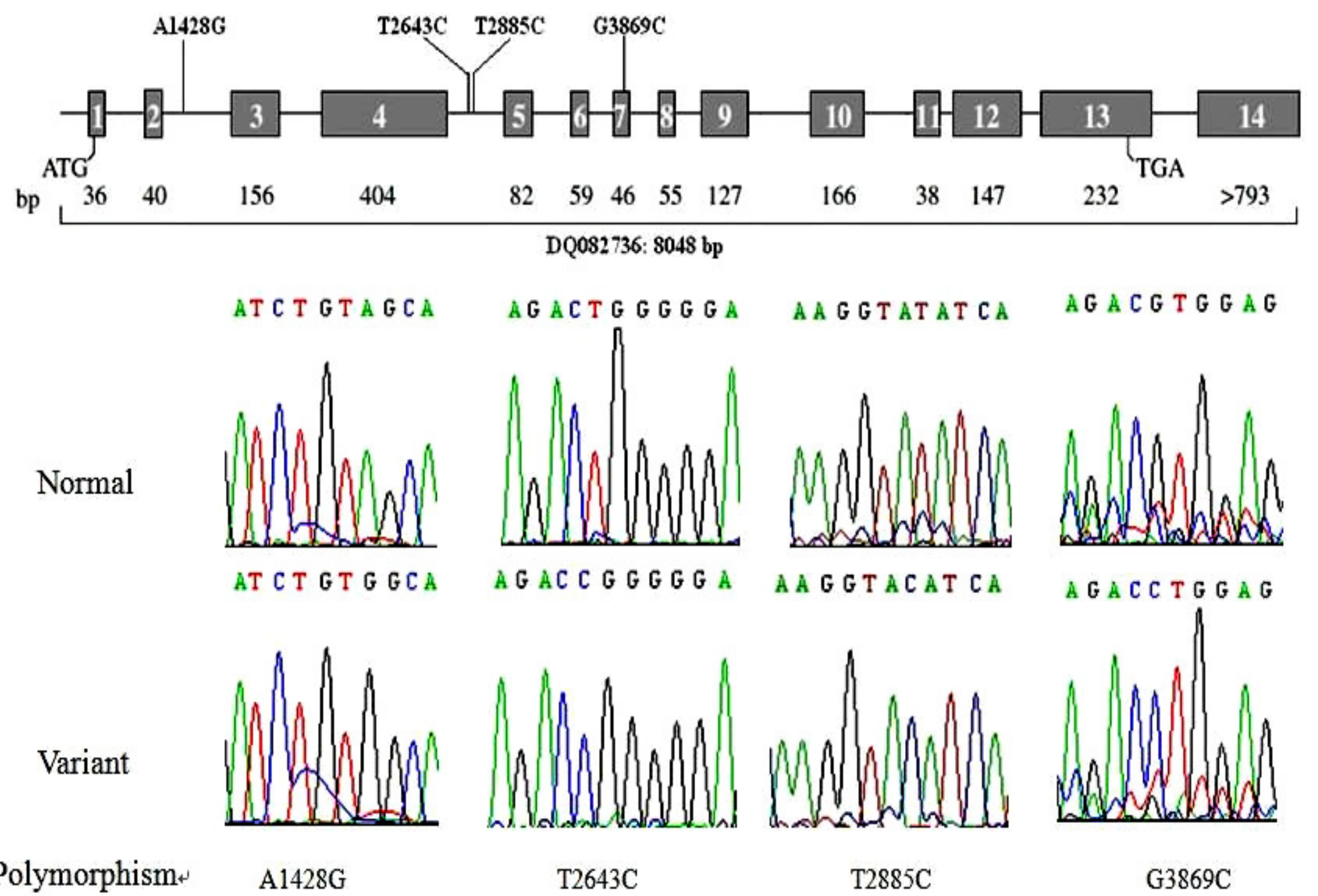

Figure 1. Chromatograms showing sequence variation at positions 1428 (A1428G), 2643 (T2643C), 2885 (T2885C) and 3869(G3869C) within the 8048 bp fragment of the PRKAG3 

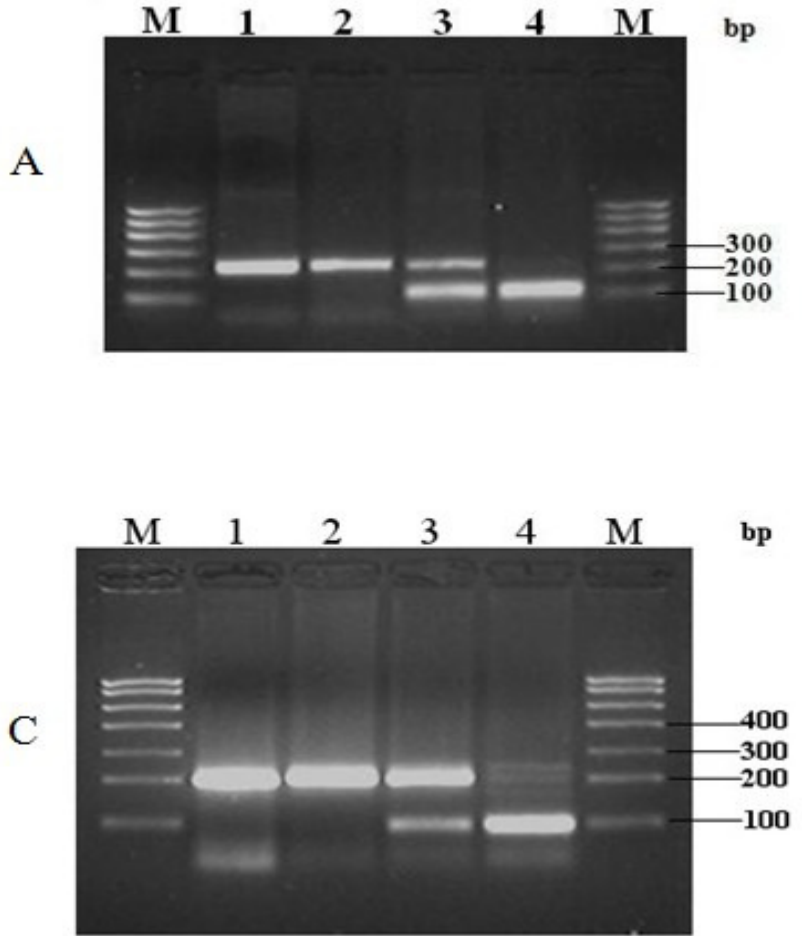
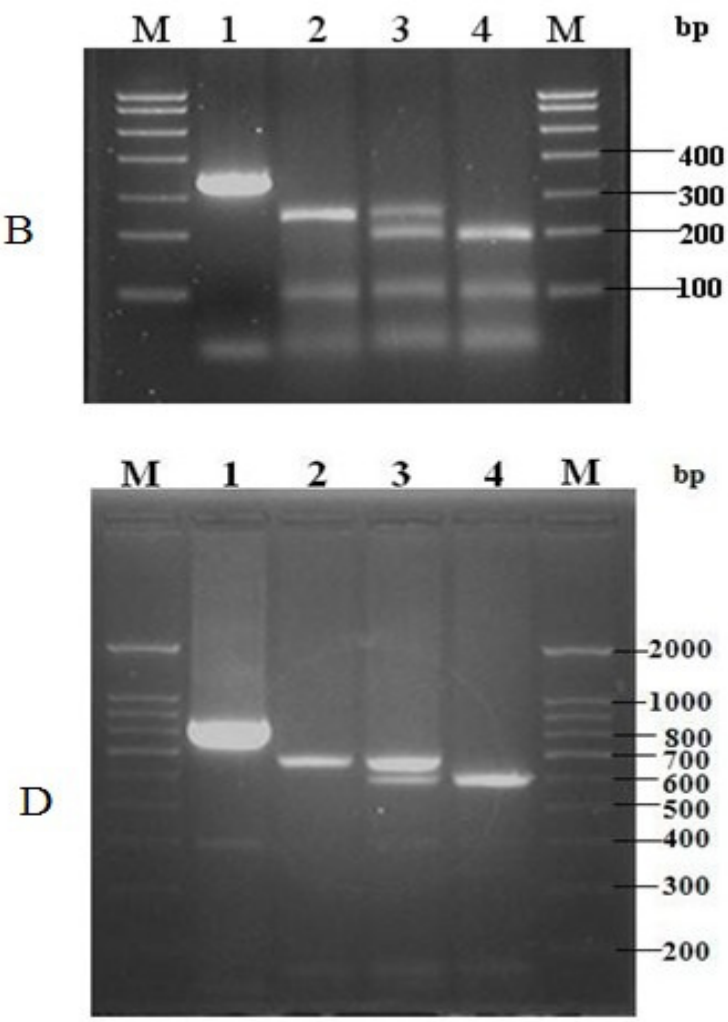

Figure 2. Sequence variation at positions 1428 (A1428G), 2643 (T2643C), 2885 (T2885C) and 3869 (G3869C) within the 8048 bp fragment of the PRKAG3 gene (DQ082736) that is cut by respective endonuclease in $3 \%$ agarose gel. A, Bfm I-RFLP patterns of PCR products of A1428G site: 1, 221 bp PCR product of P1 primer; 2, GG; 3, AG; 4, AA; B, Bcn I-RFLP patterns of PCR product of T2643C site: 1, 326 bp PCR product of P2 primer; 2, TT; 3, TC; 4, CC; C, Rsa I-RFLP patterns of PCR products of T2885C site: 1203 bp PCR product of P3 primer; 2, TT; 3, TC; 4, CC; D, Tai I-RFLP patterns of PCR products of G3869C site: 1, 843 bp PCR product of P4 primer; 2, CC; 3, GC; 4, GG; M, DNA marker, respectively.

Table 3. Genotype frequencies within different breeds for the four SNPs in the PRKAG3 gene.

\begin{tabular}{|c|c|c|c|c|c|c|c|c|c|}
\hline \multirow[b]{2}{*}{ SNP } & \multirow[b]{2}{*}{ Genotype } & \multicolumn{7}{|c|}{ Breed (number) } & \multirow{2}{*}{$\begin{array}{c}\text { Total } \\
(N=267)\end{array}$} \\
\hline & & $\begin{array}{c}\text { Simmental } \\
(\mathrm{N}=107)\end{array}$ & $\begin{array}{l}\text { Angus } \\
(N=44)\end{array}$ & $\begin{array}{l}\text { Hereford } \\
(\mathrm{N}=30)\end{array}$ & $\begin{array}{c}\text { Charolais } \\
(\mathrm{N}=\mathbf{2 8})\end{array}$ & $\begin{array}{c}\text { Limousin } \\
(\mathrm{N}=19) \\
\end{array}$ & $\begin{array}{c}\text { Luxi } \\
(\mathrm{N}=20)\end{array}$ & $\begin{array}{l}\text { Jinnan } \\
(N=19)\end{array}$ & \\
\hline \multirow{3}{*}{ A1428G } & $A A$ & $39.25(42)$ & $20.45(9)$ & $10.00(3)$ & $39.29(11)$ & $26.32(5)$ & $5.00(1)$ & $5.26(1)$ & $26.97(72)$ \\
\hline & $A G$ & $49.53(53)$ & $56.82(25)$ & $36.67(11)$ & $46.43(13)$ & $57.89(11)$ & $40.00(8)$ & $63.16(12)$ & $49.81(133)$ \\
\hline & GG & $11.21(12)$ & $22.73(10)$ & $53.33(16)$ & $14.29(4)$ & $15.79(3)$ & $55.00(11)$ & $31.58(6)$ & $23.22(62)$ \\
\hline \multirow{3}{*}{ T2643C } & $\mathrm{TT}$ & $42.99(46)$ & $20.45(9)$ & $3.33(1)$ & $35.71(10)$ & $26.32(5)$ & $5.00(1)$ & $5.26(1)$ & $27.34(73)$ \\
\hline & TC & $42.99(46)$ & $54.55(24)$ & $36.67(11)$ & $53.57(15)$ & $63.16(12)$ & $50.00(10)$ & 78.95 (15) & $49.81(133)$ \\
\hline & $\mathrm{CC}$ & $14.02(15)$ & $25.00(11)$ & $60.00(18)$ & $10.71(3)$ & $10.53(2)$ & $45.00(9)$ & $15.79(3)$ & $22.85(61)$ \\
\hline \multirow{3}{*}{ T2885C } & $\mathrm{TT}$ & 33.64 (36) & $38.64(17)$ & $86.67(26)$ & $28.57(8)$ & $42.11(8)$ & $70.00(14)$ & $42.11(8)$ & $43.82(117)$ \\
\hline & TC & $42.06(45)$ & $54.55(24)$ & $13.33(4)$ & $53.57(15)$ & $47.37(9)$ & $25.00(5)$ & $52.63(10)$ & $41.95(112)$ \\
\hline & $\mathrm{CC}$ & $24.30(26)$ & $6.82(3)$ & $0.00(0)$ & $17.86(5)$ & $10.52(2)$ & $5.00(1)$ & $5.26(1)$ & $14.23(38)$ \\
\hline \multirow{3}{*}{ G3869C } & GG & $76.64(82)$ & $47.73(21)$ & $70.00(21)$ & 78.57 (22) & $68.42(13)$ & $35.00(7)$ & $26.32(5)$ & $64.04(171)$ \\
\hline & $\mathrm{GC}$ & $20.56(22)$ & $43.18(19)$ & $30.00(9)$ & $17.86(5)$ & 15.79 (3) & $45.00(9)$ & $68.42(13)$ & $29.96(80)$ \\
\hline & $\mathrm{CC}$ & $2.80(3)$ & $9.09(4)$ & $0.00(0)$ & 3.57 (1) & $15.79(3)$ & $20.00(4)$ & $5.26(1)$ & $6.00(16)$ \\
\hline
\end{tabular}

The location of the SNP in the sequence DQ082736. 
Table 4. Effects of four different SNPs genotypes on phenotypic traits in beef cattle.

\begin{tabular}{|c|c|c|c|c|c|c|c|c|c|c|c|}
\hline \multirow{2}{*}{ SNP } & \multirow{2}{*}{ Genotype } & \multirow{2}{*}{ Number } & \multicolumn{9}{|c|}{ Traits $^{*}($ mean \pm SE) } \\
\hline & & & LW (kg) & CW (kg) & DP (\%) & $\mathrm{BF}(\mathrm{cm})$ & LMA $\left(\mathrm{cm}^{2}\right)$ & $\mathrm{MC}(1-6)$ & $\mathrm{FC}(1-7)$ & MS (1-5) & TD (kg) \\
\hline \multirow{4}{*}{ A1428G } & AA & 72 & $553.84 \pm 9.71$ & $311.69 \pm 6.44$ & $55.76 \pm 0.53$ & $1.21 \pm 0.08$ & $70.22 \pm 1.90$ & $4.58 \pm 0.13$ & $1.38 \pm 0.07$ & $2.29 \pm 0.16$ & $4.50 \pm 0.23$ \\
\hline & $A G$ & 133 & $567.29 \pm 8.94$ & $313.94 \pm 5.93$ & $55.09 \pm 0.49$ & $1.27 \pm 0.07$ & $71.46 \pm 1.75$ & $4.56 \pm 0.12$ & $1.32 \pm 0.07$ & $2.12 \pm 0.15$ & $4.16 \pm 0.21$ \\
\hline & $G G$ & 62 & $576.48 \pm 10.58$ & $321.88 \pm 7.01$ & $55.61 \pm 0.58$ & $1.20 \pm 0.08$ & $72.79 \pm 2.07$ & $4.51 \pm 0.14$ & $1.23 \pm 0.08$ & $2.33 \pm 0.19$ & $4.09 \pm 0.25$ \\
\hline & $P$ & & 0.0947 & 0.3028 & 0.2677 & 0.5499 & 0.4653 & 0.8945 & 0.1635 & 0.2519 & 0.1639 \\
\hline \multirow[t]{4}{*}{ T2643C } & TT & 73 & $556.30 \pm 10.01$ & $313.03 \pm 6.62$ & $55.87 \pm 0.54$ & $1.25 \pm 0.08$ & $69.91 \pm 1.95$ & $4.64 \pm 0.13$ & $1.41 \pm 0.07$ & $2.22 \pm 0.17$ & $4.43 \pm 0.24$ \\
\hline & $\mathrm{TC}$ & 113 & $565.78 \pm 8.90$ & $313.18 \pm 5.88$ & $54.99 \pm 0.48$ & $1.23 \pm 0.07$ & $71.24 \pm 1.73$ & $4.55 \pm 0.12$ & $1.31 \pm 0.06$ & $2.23 \pm 0.15$ & $4.23 \pm 0.21$ \\
\hline & $\mathrm{CC}$ & 61 & $573.94 \pm 10.68$ & $321.16 \pm 7.06$ & $55.79 \pm 0.58$ & $1.22 \pm 0.08$ & $73.46 \pm 2.08$ & $4.45 \pm 0.14$ & $1.21 \pm 0.08$ & $2.24 \pm 0.18$ & $4.10 \pm 0.25$ \\
\hline & $P$ & & 0.2707 & 0.3895 & 0.0832 & 0.9434 & 0.2429 & 0.4384 & 0.0557 & 0.9910 & 0.4152 \\
\hline \multirow[t]{4}{*}{ T2885C } & TT & 117 & $565.23 \pm 9.43$ & $314.07 \pm 6.23$ & $55.28 \pm 0.01$ & $1.23 \pm 0.07$ & $72.56 \pm 1.82$ & $4.46 \pm 0.13$ & $1.25 \pm 0.07$ & $2.25 \pm 0.16$ & $3.98^{\mathrm{a}} \pm 0.22$ \\
\hline & TC & 112 & $568.15 \pm 9.20$ & $316.79 \pm 6.08$ & $55.49 \pm 0.01$ & $1.28 \pm 0.07$ & $71.68 \pm 1.78$ & $4.54 \pm 0.12$ & $1.37 \pm 0.07$ & $2.26 \pm 0.15$ & $4.38^{b} \pm 0.21$ \\
\hline & $\mathrm{CC}$ & 38 & $557.28 \pm 11.58$ & $312.88 \pm 7.65$ & $55.60 \pm 0.01$ & $1.17 \pm 0.09$ & $68.42 \pm 2.24$ & $4.77 \pm 0.15$ & $1.36 \pm 0.09$ & $2.11 \pm 0.19$ & $4.55^{b} \pm 0.27$ \\
\hline & $P$ & & 0.5986 & 0.7967 & 0.8441 & 0.3583 & 0.1766 & 0.1303 & 0.1384 & 0.7052 & 0.0388 \\
\hline \multirow[t]{4}{*}{ G3869C } & GG & 171 & $564.37 \pm 8.50$ & $314.97 \pm 5.62$ & $55.50 \pm 0.46$ & $1.22 \pm 0.07$ & $70.55 \pm 1.63$ & $4.58 \pm 0.11$ & $1.32 \pm 0.06$ & $2.23 \pm 0.14$ & $4.32 \pm 0.20$ \\
\hline & GC & 80 & $565.15 \pm 10.47$ & $312.54 \pm 6.92$ & $55.04 \pm 0.57$ & $1.23 \pm 0.08$ & $73.77 \pm 2.01$ & $4.62 \pm 0.14$ & $1.34 \pm 0.08$ & $2.26 \pm 0.18$ & $4.10 \pm 0.24$ \\
\hline & $\mathrm{CC}$ & 16 & $545.83 \pm 16.43$ & $306.11 \pm 10.7$ & $55.77 \pm 0.89$ & $1.24 \pm 0.13$ & $71.64 \pm 3.16$ & $4.31 \pm 0.22$ & $1.36 \pm 0.12$ & $2.03 \pm 0.28$ & $4.08 \pm 0.38$ \\
\hline & $P$ & & 0.4295 & 0.6505 & 0.5099 & 0.9661 & 0.1309 & 0.3063 & 0.8982 & 0.6605 & 0.4795 \\
\hline
\end{tabular}

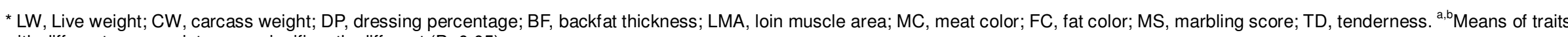
with different superscripts were significantly different $(P<0.05)$.

potential effects on tenderness trait. Therefore, further work will be necessary to use these SNPs for marker assisted selection (MAS) in a larger population and to investigate whether the PRKAG3 gene plays a role in intramuscular fat deposition or is in linkage disequilibrium with other causative mutations.

\section{ACKNOWLEDGEMENTS}

This work was sported by the Twelfth "Five-Year"
National Science and Technology Supported Project (grant no. 2011BAD28B04), and the Twelfth "Five-Year" National Transgenic Major Special Project (grant no. 2008ZX08007-2).

\section{REFERENCES}

Carling D (2004). The AMP-activated protein kinase cascade-a unifying system for energy control. Trends. Biochem. Sci. 29 8-24.

Cheung PC, Salt IP, Davies SP, Hardie DG, Carling D (2000).

Characterization of AMP-activated protein kinase gamma-subunit isoforms and their role in AMP binding. Biochem. J. 346(3): 659-669

Ciobanu D, Bastiaansen J, Ciobanu D, Bastiaansen J, Malek M, Helm J, Woollard J, Plastow G, Rothschild M (2001). Evidence for new alleles in the protein kinase adenosine monophosphate-activated gamma(3)-subunit gene associated with low glycogen content in pig skeletal muscle and improved meat quality. Genetics, 159: 1151-1162.

Ferre P, Azzout-Marnich D, Foufelle F (2003). AMP-activated protein kinase and hepatic genes involved in glucose metabolism. Biochem. Soc. T. 31: 220-223.

Hardie DG, Carling D, Carlson M (1998). The AMP-activated/SNF1 protein kinase subfamily:metabolic sensors of the eukaryotic cell? Annu. Rev. Biochem. 67: 
821-855.

Hardie DG, Scott JW, Pan DA, Hudson ER (2003). Management of cellular energy by the AMP-activated protein kinase system. FEBS. Lett. 546: 113-120.

Hawley SA, Davison M, Woods A, Davies SP, Beri RK, Carling D, Hardie DG (1996). Characterization of the AMP-activated protein kinase kinase from rat liver, and identification of threonine 172 as the major site at which it phosphorylates and activates AMPactivated protein kinase. J. Biol. Chem. 271: 27879-27887.

Immonen K, Ruusunen M, Hissa K, Puolanne E (2000). Bovine muscle glycogen concentration in relation to finishing diet, slaughter and ultimate $\mathrm{pH}$. Meat Sci. 55: 25-31.

Kemp BE, Mitchelhill KI, Stapleton D, Michell BJ, Chen ZP, Witters LA (1999). Dealing with energy demand: the AMP-activated protein kinase. Trend Biochem. Sci. 24: 22-25.

Milan D, Jeon JT, Looft C, Amarger V, Robic A, Thelander M, Rogel-Gaillard C, Paul S, lannuccelli N, Rask L, Ronne H, Lundström K, Reinsch N, Gellin J, Kalm E, Roy PL, Chardon P, Andersson L (2000). A mutation in PRKAG3 associated with excess glycogen content in pig skeletal muscle. Science, 288: 1248-1251.

Mullenbach R, Lagoda PJ, Welter C (1989). An efficient salt-chloroform extraction of DNA from blood and tissues. Trends Genet. 5: p. 391.

Rothschild M, Ciobanu D, Malek M, Plastow G (2005). PRKAG3 alleles and use of the same as genetic markers for reproductive and meat quality traits: US Patent. 6(919): 177.
Roux M, Nizou A, Forestier L, Ouali A, Levéziel H, Amarger V (2006). Characterization of the bovine PRKAG3 gene: structure, polymorphism, and alternative transcripts. Mamm. Genome, 17(1): 83-92.

Stapleton D, Mitchelhill KI, Gao G, Widmer J, Michell BJ, Teh T, House CM, Fernandez CS, Cox T, Witters LA, Kemp BE (1996). Mammalian AMP-activated protein kinase subfamily. J. Biol. Chem. 271: 611-614.

Thornton C, Snowden MA, Carling D (1998). Identification of a novel AMP-activated protein kinase beta subunit isoform that is highly expressed in skeletal muscle. J. Biol. Chem. 273: 12443-12450.

Winder WW (2001). Energy-sensing and signaling by AMP-activated protein kinase in skeletal muscle. J. Appl. Physiol. 91: 1017-1028.

Yu SL, Kim JE, Chung HJ, Jung KC, Lee YJ, Yoon DH, Lee SH, Choi I, Bottema CD, Sang BC, Lee JH (2005). Molecular cloning and characterization of bovine PRKAG3 gene: structure, expression and single nucleotide polymorphism detection. J. Anim. Breed. Genet. 122(5): 294-301. 